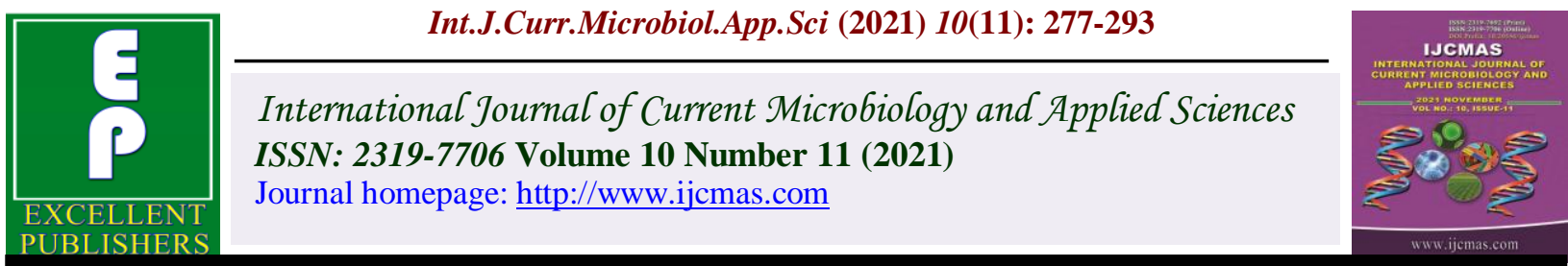

\title{
Post-Harvest Control of Anthracnose of Mango (Mangifera indica $L$. var Kent) using Essential Oils Extracted from two Aromatic Plants (Cymbopogon citratus (D C) Stapf. and Melaleuca quinquenervia L.) of the Ivorian Flora
}

\author{
KOUAME Koffi Gaston ${ }^{1}$, KOUAME Konan Didier ${ }^{2}$, \\ KASSI Koffi Fernand Jean-Martial ${ }^{2}$ and KONE Daouda ${ }^{2}$
}
${ }^{1}$ Department of Plant Biology, Training and Research Unit of Biological Sciences, Peleforo- Gon-Coulibaly University B.P. 1328 Korhogo, Côte d'Ivoire
${ }^{2}$ Laboratory of Biotechnology, Agriculture and Valorisation of Biological Resources, Pedagogy and Research Unit of Plant Physiology and Pathology, UFR Biosciences of Félix Houphouët- Boigny University, 22 B.P.582 Abidjan 22; Côte d'Ivoire

*Corresponding author

\begin{tabular}{|l|}
\hline Ke y w o r d s \\
Mangifera indica, \\
Anthracnose, \\
Essential oil; \\
$\begin{array}{l}\text { Cymbopogon } \\
\text { citratus; } \text { Melaleuca } \\
\text { quinquenervia }\end{array}$ \\
\hline Article Info \\
\hline $\begin{array}{l}\text { Received: } \\
\text { 01 October } 2021 \\
\text { Accepted: } \\
\text { 06 November } 2021 \\
\text { Available Online: } \\
\text { 10 November } 2021\end{array}$ \\
\hline
\end{tabular}

\section{A B S T R A C T}

Mango anthracnose is one of the most important mango diseases in Côte d'Ivoire. The chemical approach to control this disease is today decried by consumers, because of the pesticide residues left in the fruit. The search for alternative control solutions, that respect the environment and are less polluting is becoming a necessity. Thus, the use of essential oils in the protection of mangoes against fruit pests before and especially after harvest is a promising solution. The present study aimed to reveal the inhibitory efficacy of essential oil of Melaleuca quinquenervia L. and Cymbopogon citratus (D.C) Stapf against Colletotrichum gloeosporioides (Penz.) Penz \& Sacc causal agent of mango anthracnose, stored at room temperature. Five doses $(100 ; 200 ; 500 ; 1,000$ and 2,000 $\mathrm{ppm}$ ) of each product were tested in vitro on mycelial growth and spore germination of $C$. gloeosporioides. In vivo, 700 and 1,400 ppm of C. citratus L. and 1,200 and 12,000 ppm of M. quinquenervia L. were tested against anthracnose in artificially inoculated mangoes. The impact of the different doses of these species on the physico-chemical parameters of the treated fruits was evaluated on day 11. Results showed that mycelial growth and spore germination were totally inhibited by $C$. citratus essential oil at 1,000 and 2,000 ppm throughout the experiment. In Vivo, the $1,200 \mathrm{ppm}$ dose of $M$. quinquenervia strongly reduced the occurrence and progression of anthracnose in treated fruits compared to the control with an efficiency rate of $77.76 \pm 8.73$ and $86.63 \pm 5.21 \%$, respectivement. The essences did not significantly influence the physico-chemical parameters of the fruits. The doses 1,200 ppm of $M$. quinquenervia and 1,400 ppm of $C$. citratus can be recommended in a post-harvest biological control strategy against mangoes anthracnose. 


\section{Introduction}

Mango (Mangifera indica L.) is a tropical fruit of high economic and social importance. World mango production is estimated at more than 55 million tons (1). In Côte d'Ivoire, mango is mainly cultivated in the North, with an annual production estimated at more than 150,000 tons (2). Almost all mango production is carried out by small producers and is constantly increasing. Similarly, the area covered by mango cultivation has improved significantly. It has increased from 10,000 ha to over 20,000 ha in 20 years (1). The export of Ivorian mango has also undergone a remarkable evolution. Indeed, the volumes of exported mangoes are constantly increasing, from 10,179 tons in 2011 to 35,124 tons in $2020(3 ; 4)$. The mango sector improves the income of producers and other stakeholders in the sector. In addition, mango plantations, packaging and processing units provide employment for many people $(2 ; 3)$. It thus contributes to poverty reduction in the production areas.

Despite this performances, the mango sector's survival is threatened by numerous phytosanitary problems (2). Indeed, in addition to the harmful action of the fruit fly and bacterial blight, fungal pathologies, particularly anthracnose, cause numerous of damage before and after the mango harvest. Anthracnose is one of the most important fungal diseases of fruit caused by the fungus Colletotrichum gloeosporioides Penz. It occurs in all mango producing areas. It is the main cause of post-harvest losses during the whole process of packaging, transport, storage and marketing of mangoes $(5 ; 6)$. Control of anthracnose is therefore necessary to preserve the quality and extend the shelf life of fruits. Chemical control is the main approach used to effectively reduce fruit losses caused by postharvest fungal pests (7). It employs a range of pesticides such as the Benzimidazole groups, imidazoles (Prochloraz, Imazalil), triazoles which have proved to be very effective. But, major mango buyers have enacted very strict laws restricting the use of chemical pesticides against post-harvest pathogens $(8 ; 9)$.

Thus, the search for other solutions for effective, healthy and sustainable control of mangoes post-harvest diseases becomes an imperative. In this context, several biological products such as microorganisms, chitosan, and essential oils extracted from plants are being tested to protect mangoes after harvest $(10 ; 11 ; 12)$. Among these products, essential oils seem to be a promising solution. Indeed, essential oils are volatile, biodegradable and rapidly degradable in natural conditions. These qualities make them healthy and environmentally friendly phytosanitary products. Furthermore, the antifungal, antibacterial and antiviral properties of essential oils against several microorganisms have been proven $(13 ; 14 ; 15)$. Moreover, these oils are accepted by consumers (16). All these properties give essential oils the advantage of being used for pre-harvest and especially post-harvest control of fruit pests. The present study aimed to reveal the inhibitory efficacy of Melaleuca quinquenervia L. and Cymbopogon citratus (D.C) Stapf essential oils against Colletotrichum gloeosporioides (Penz.) Penz $\&$ Sacc causal agent of mango anthracnose, stored at room temperature.

\section{Materials and Methods}

\section{Plant material}

Two types of mango samples of the 'Kent' variety were collected in a village plantation in Korhogo department. The first sample consisted of anthracnose-symptomatic mangoes used to obtain the fungal strain. The second sample consisted of asymptomatic mangoes used for biological control tests. 


\section{Fungal material}

A strain of Colletotrichum gloeosporioides used in this study was isolated from anthracnose-affected mangoes fruit at the pathology unit of plant physiology laboratory of Félix Houphouët-Boigny University, Abidjan (11).

\section{Extraction of essential oils}

The essential oils tested were extracted from fresh leaves of Cymbopogon citratus (DC) Stapf. (Poaceae) and Melaleuca quinquenervia $\mathrm{L}$ (Myrtaceae). The leaves were respectivily purchased at Abobo market and harvested at Cocody, Abidjan. The oils were obtained by hydrodistillation of the leaves through Clevenger - type -system for $2 \mathrm{~h} 30 \mathrm{~min}$. They were then kept in the freezer $\left(-10^{\circ} \mathrm{C}\right)$ before being used for the different tests.

\section{In vitro Fungal Inhibition test}

The effect of essential oils on fungal mycelial growth and spore germination was assessed in vitro.

The essential oils obtained were evaluated at the concentrations of $0 ; 100 ; 200 ; 500 ; 1000$ and $2000 \mathrm{ppm}$. The synthetic fungicide (azoxystrombin) used as a positive control was dissolved in sterile distilled water to obtain a stock solution. From this solution, dilutions were then made and incorporated into the culture medium to obtain concentrations of $0.01 ; 0.05 ; 0.1 ; 0.5$ and $1 \mathrm{ppm}$.

\section{Effect of essential oils on mycelial growth}

Each concentration of the essential oils or the synthetic fungicide were added to PDA (Potato Dextrose Agar) culture medium after autoclaving at $121^{\circ} \mathrm{C}, 1 \mathrm{bar}$ for $20 \mathrm{~min}$. The mixture was then, poured into $90 \mathrm{~mm}$ diameter Petri dishes (15 ml per dish). For each concentration of essential oil or synthetic fungicide, five Petri dishes were used. Each Petri dish was inoculated in the center with a 5 $\mathrm{mm}$ diameter mycelia disc taken from the margin of a 7-day-old young $C$. gloeosporioides cultures. The Petri dishes containing plates were incubated at $28^{\circ} \mathrm{C}$ and a photoperiod of $12 / 12$ for 12 days (11). The control was carried out under the same conditions, but without the addition of synthetic fungicide or essential oil. Mycelial growth of colonies was measured every 24 hours along two perpendicular diameters passing through the middle of the explant. The effect of essential oil was evaluated by the mycelial growth inhibition rate (Ic) according to the following formula (17):

$\mathrm{I}_{\mathrm{c}}(\%)=((\mathrm{Mo}-\mathrm{Mc}) / \mathrm{Mo}) \times 100$

Mo $=$ average growth of the fungus $(\mathrm{mm})$ on the control medium.

$\mathrm{Mc}=$ average growth of the fungus $(\mathrm{mm})$ in the culture medium at the concentration (c) of the essential oil or synthetic fungicide

In addition, explants from the test plates that did not grow were transferred to dishes containing fresh PDA medium, without oil or chemicals to assess their viability after 7 days. If mycelial growth is still inhibited, the essential oil is said to have fungicidal activity and in the contrary case, it was said to have fungistatic activity (18).

\section{Spore germination test}

Spores were collected from cultures grown on PDA for 14-day-old following the procedure described by Kouamé et al., (11). The essential oil or synthetic fungicide was directly incorporated into the agar culture medium and the mixture was poured into Petri dishes, with $10 \mathrm{ml}$ of medium per dish. $10 \mu \mathrm{l}$ of spore suspension were inoculated onto Petri 
dishes containing agar medium following two marked parallels lines under each plate to easy spore counting. Three replicates were performed simultaneously per concentration. Incubation was done at $28^{\circ} \mathrm{C}$ and 200 spores per dish were evaluated under the microscope to determine the germination rate every 6 hours. The percentage of spore germination inhibition (Ig) was determined according to the following formula (19):

$\operatorname{Ig}(\%)=(($ So - Sc $) /$ So $) \times 100$

So $=$ number of germinated spores in the control culture medium

$\mathrm{Sc}=$ number of germinated spores in the presence of a concentration (c) of the essential oil or synthetic fungicide.

Concentrations reducing mycelial growth or spore germination by $50 \%\left(\mathrm{EC}_{50}\right)$ and $90 \%$ $\left(\mathrm{EC}_{90}\right)$ were determined for each product used after 7 days of mycelial growth or 24 hours of spore germination. They were determined from the linear regression equation between the logarithms of the concentrations (x-axis) and the average rates of reduction of mycelial growth and/or spore germination (y-axis; (19)).

Along with the growth measurement, the Minimum Inhibitory Concentration (MIC) was detected. MIC was considered as the lowest concentration of the product used at which no mycelial growth or spore germination was observed (20).

\section{In vivo antifungal assay}

The in vivo efficacy of essential oil of $C$. citratus at 700 and $1400 \mathrm{ppm}$ and $M$. quinquenervia at 1200 and 12081 ppm was evaluated on mango fruit. Both concentrations of each oil were prepared by dissolving first $0.35 ; 0.7 \mathrm{ml}$ of $C$. citratus 0.6 and $6.04 \mathrm{ml}$ of
M. quinquenervia in $25 \mathrm{ml}$ of $0.01 \%$ Tween 20; then added to $475 \mathrm{ml}$ of sterile distilled water (21). Mango fruits of the Kent variety healt visibly, undamaged and disease free were obtained from a plantation in Korhogo department. The fruits were sterilized by soaking them in a sodium hypochlorite solution $(1 \%)$ for $5 \mathrm{~min}$, then rinsed three times with sterile distilled water and air-dried in the culture room. A total of 45 fruits, divided into 09 batches (5 fruits per batch) were used for this study. Each batch corresponded to one treatment. Five small uniform wounds of $5 \mathrm{~mm}$ depth and $0.66 \mathrm{~mm}$ diameter were made on the skin of the fruits of nine batches using a sterile needle at 5 separate points on each fruit. Fruits were then inoculated by injecting $10 \mu \mathrm{l}$ of $C$. gloeosporioides spore suspension $\left(1.6 \times 10^{4}\right.$ spores/ml) into each wounded spot. Eight batches were soaked for $1 \mathrm{~min}$ in a specific concentration of the two essential oils (2 batches per concentration) before or $30 \mathrm{~min}$ after inoculation. The control batch was soaked in sterile distilled water. Each batch of treated fruit was placed in a cardboard box and incubated in the culture room at $28 \pm 2{ }^{\circ} \mathrm{C}$. The experiment was performed twice.

The effect of the two essential oils on disease incidence, disease progression and efficacy of each treatment were evaluated for 11 days. After 48 hours, fruits inoculated were daily observed and the number of points that produced lesions was recorded.

Disease incidence (DI) data are presented as the percentage of inoculated points with anthracnose or lesion (Ns) over the total number of inoculated spots $(\mathrm{Nt})$ in each treatment. The DI for each treatment was calculated according to the formula adapted from Nutter et al., (22).

In addition, the evolution of the lesions was also measured along 2 perpendicular lines. 
Then, the average lesion diameter (D) was calculated as follows:

$\mathrm{D}(\mathrm{mm})=(\mathrm{d} 1+\mathrm{d} 2) / 2$

Where $\mathrm{d} 1$ was the length of the lesion along the long axis of the fruit and $\mathrm{d} 2$ was the length of the lesion along the short axis of the fruit.

Furthermore, the efficacy of each treatment (E) on disease manifestation and progression was calculated as described by Kouakou et al., (23) with the formula: ((Lo - Li) / Lo) x 100, where Lo was the disease lesion rate or lesion size on control fruit and Li was the lesion rate or lesion size on the treated fruit.

\section{Effect of oils on physico-chemical parameters}

The influence of different doses of Cymbopogon citratus and Melaleuca quinquenervia essential oils on different physical and biochemical parameters of treated and control fruits was evaluated on the $11^{\text {th }}$ day of incubation.

\section{Physical quality parameters}

\section{Mass loss}

The fruits of each treatment were marked before, and mass of fruit was measured using a Sartorius balance $(0.001 \mathrm{~g})$. The fruits were weighed at the beginning (Mi) of the experiment and at the end of storage period (Mf). The mass loss (ML) was evaluated according to the formula of Fawole and Opara (24).

$\operatorname{ML}(\%)=((\mathrm{Mi}-\mathrm{Mf}) / \mathrm{Mi}) \times 100$

\section{Firmness}

The firmness of whole fruits was determined using a crossbow-type penetrometer. It consisted in evaluating the resistance to penetration of the cylindrical tip of the instrument (length $=8 \mathrm{~mm}$, diameter $=3 \mathrm{~mm}$ ) inside the fruit.

Firmness was measured at 4 points (2 lateral, one dorsal and one ventral); and the maximum compression force was expressed in Newtons (N) (25). The average of the measurements was calculated for each fruit.

\section{Biochemical quality parameters}

\section{Titratable acidity (TA)}

The titratable acidity was analysed using titratable method. Pulp tissue (3g) from each fruit was homogenized using a kitchen blender with $30 \mathrm{ml}$ of distilled water and filtered.

Then, $10 \mathrm{ml}$ of the filtrate with 3-4 drops of phenophthalein $(0.1 \%)$ as indicator was titrated against $0.1 \mathrm{~N}$ sodium hydroxide $(\mathrm{NaOH})$ solution to a pink endpoint $(\mathrm{pH} 8.1)$. The results were expressed as the percentage of citric acid per $100 \mathrm{~g}$ fresh weight (25).

\section{Soluble sugar content (SSC)}

Soluble sugar concentration was measured using a Digital hand Refractometer (Atago pr1). The refractometer was previously calibrated with distilled water.

Measurements were then made by covering the surface of the prism surface with fraction of the previously filtrate. The displayed value was noted. Two measurements were made per filtrate and the results were expressed as mean $\pm \mathrm{SE}{ }^{\circ}$ Brix.

\section{pH}

The $\mathrm{pH}$ of the fruit pulp juice was determined using a digital hand $\mathrm{pH}$ meter calibrated by $\mathrm{pH}$ 4 and 7 buffer solutions. 


\section{Statistical analysis}

Experimental data were analyzed using analysis of variance (ANOVA) via STATISTICA 7.1 software. The means of treatments were compared by using NewmanKeuls's test at 5\% significance level.

\section{Results and Discussion}

\section{Effect of essential oils on mycelial growth}

The susceptibility of $C$. gloeosporioides varied according to the dose, the product used and the incubation time. Inhibition of mycelial growth increased with the dose of the oil used. Figure 1 shows the average rate of mycelial growth reduction of $C$. gloeosporioides treated with the different doses of Melaleuca quinquenervia essential oil. Concentrations of 100 and $200 \mathrm{ppm}$ induced a low average rate of mycelial growth reduction. This rate varied respectively from $38.12 \pm 3.36$ to $2.98 \pm$ $1.13 \%$ and from $50.30 \pm 5.56$ to $14.47 \pm$ $7.79 \%$, from day 1 to day 9 . For the $1000 \mathrm{ppm}$ and $2000 \mathrm{ppm}$ doses, the reduction rate decreased from $100 \%$ on day 1 to $26.09 \pm 2.57$ and $44.14 \pm 2.67 \%$ on day 9 , respectively. The $\mathrm{EC}_{50}$ on day 7 was $1249 \mathrm{ppm}$ and the $\mathrm{EC}_{90}$ was $12081 \mathrm{ppm}$. The essential oil of Cymbopogon citratus strongly inhibited mycelial growth. The average reduction rate varied from 2.14 to $100 \%$ (Figure 2). Fungal growth was completely inhibited $(100 \%)$ by the 1000 and $2000 \mathrm{ppm}$ concentrations throughout the experiment. The $1000 \mathrm{ppm}$ dose is therefore the minimum total inhibitory concentration for mycelial growth. In addition, the $\mathrm{EC}_{50}$ was 452 ppm on day 7 of incubation and the $\mathrm{EC}_{90}$ was $1301 \mathrm{ppm}$.

A strong fungitoxic activity on mycelial growth was expressed by the different doses of Azoxystrombin used (Figure 3). The reduction rates of mycelial growth obtained ranged from 39.41 to $100 \%$ depending on the concentrations. The $\mathrm{EC}_{50}$ and $\mathrm{EC}_{90}$ obtained on day 7 were 0.01 and $0.56 \mathrm{ppm}$, respectively. Furthermore, only the $C$. citratus essential oil was able to show an MIC. Mycelial explant in culture media amended with this essential oil at the dose of $1000 \mathrm{ppm}$ showed a recovery of $62 \%$. In contrast, no recovery was obtained with the $2000 \mathrm{ppm}$ concentration. C. citratus is therefore fungistatic for C. gloeosporioides (Penz) at $1000 \mathrm{ppm}$ and fungicidal at $2000 \mathrm{ppm}$.

\section{Effect of essential oils on spore germination}

The germination of $C$. gloeosporioides (Penz) Penz \& Sacc. spores was inhibited by the different essential oils and synthetic fungicides used (Table 1).

The $M$. quinquenervia essential oil had a moderate inhibitory activity on spore germination. The reduction rates obtained varied from $40.2 \pm 9.6$ to $89.7 \pm 4.2 \%$ after 24 $\mathrm{h}$ of incubation (Table 1). The concentrations that inhibited 50 and $90 \%$ of spore germination were $193.5 \mathrm{ppm}$ and $2125.5 \mathrm{ppm}$, respectively. Neither concentration completely inhibited germination after $24 \mathrm{~h}$ of incubation. C. citratus essential oil showed a very high fungitoxic activity on spore germination with all five doses used. These concentrations resulted in an average reduction of spore germination of more than $70 \%$ throughout the experiment (Table 1). After $24 \mathrm{~h}$ of incubation, the 1000 and $2000 \mathrm{ppm}$ concentrations completely inhibited spore germination (Table 1). The minimum inhibitory concentration (MIC) for 100\% germination was $1000 \mathrm{ppm}$. The $\mathrm{EC}_{50}$ and $\mathrm{EC}_{90}$ were $0.002 \mathrm{ppm}$ and $112.20 \mathrm{ppm}$, respectively.

The synthetic fungicide "Azoxystrombin" showed a strong inhibitory activity on spore germination. The reduction rates obtained varied from $71.7 \pm 6.8$ to $98.1 \pm 0.7 \%$ after 24 
$\mathrm{h}$ of exposure of spores to different doses of the product (Table 1). The $\mathrm{EC}_{50}$ and $\mathrm{EC}_{90}$ were 0.0003 and $0.25 \mathrm{ppm}$, respectively and no MIC was obtained for spores at the different doses used (Table 1).

In sum, both life stages of $C$. gloeosporioides were strongly reduced by the different doses of the two essential oils used. Overall, the inhibitory activity of the oils was more pronounced on spore germination than on mycelial growth.

In vivo activity of $M$. quinquenervia and $C$. citratus essential oils

Concentrations C1 (700 ppm) and C2 (1400 ppm) of $C$. citratus essential oil and $\mathrm{C}_{\mathrm{M}}(1200$ $\mathrm{ppm})$ of $M$. quinquenervia revealed the curative and protective capacities of these two essences on post-harvest mangoes against anthracnose.

The dose $\mathrm{C} 2$ of $C$. citratus and the single $\mathrm{C}_{\mathrm{M}}$ dose of $M$. quinquenervia prevented the occurrence of the disease on fruits inoculated before or after the treatment until the $7^{\text {th }}$ day of incubation. From this date until the end of the experiment, fruits treated with both doses showed increasing infection rates.

In addition, fruits treated curatively with dose C2 showed low lesion rates compared to the preventive method throughout the experiment (Figure 4). However, fruits treated with $M$. quinquenervia essential oil showed statistically identical infection rates $(p=$ 0.085240) during the trials (Figure 5). Furthermore, statistical analyses indicated that both doses of $C$. citratus and $M$. quinquenervia oil significantly $(p=0.0000)$ reduced the incidence of the disease on treated fruits (Table 2). Regarding $C$. citratus essential oil, the $\mathrm{C} 2$ dose provided significant $(p=0.0046)$ protection of the fruits compared to the control. It induced an efficacy (E) of
$68.33 \pm 4.16 \%$ as a curative measure, while the $\mathrm{C} 1$ treatment presented an efficacy (E) of $54.08 \pm 5.33 \%$ (Table 2). As for the single dose of $M$. quinquenervia, the efficacy (G) induced on the disease manifestation in treated fruits was $75.64 \pm 9.96 \%$ for curative and $77.76 \pm 8.73 \%$ for preventive method (Table $2)$. Thus, the efficacy of this concentration did not differ significantly for either method ( $p=$ $0.05817)$.

Furthermore, the progression of disease symptoms on the fruits was influenced by the treatments (Table 2). Ultimately, C2 reduced disease symptom development by $79.20 \pm$ $3.59 \%$ compared to the control (Table 2). In addition, fruits treated with the same dose showed lesion size of $0.18 \pm 0.03 \mathrm{~cm}$. It had similar inhibitory activity and efficacy as a preventive and curative measure. In contrast, $\mathrm{C} 1$ dose weakly reduced symptom progression by $15.58 \pm 10.83 \%$ as a preventive measure (Table 2). Similarly, the efficacy of the $\mathrm{C}_{M}$ dose on lesion progression was $85.88 \pm 4.86$ and $86.67 \pm 5.21 \%$ according to the two methods used (Table 2).

Influences of essential oils on some physicochemical parameters of treated fruits

\section{Mass loss}

The rates of fruits mass loss recorded with the $\mathrm{C} 1$ and $\mathrm{C} 2$ doses of $C$. citratus essential oil were $11.94 \pm 1.68$ and $9.54 \pm 0.93 \%$. These rates were statistically identical to that of the control ( $P=0.06982$; Table 3$)$. For the only dose of $M$. quinquenervia evaluated, it induced a significant mass loss $(p=$ 0.026682 ). Indeed, the mass loss induced by the fruits treated with this oil was 12.65 $\pm 1.74 \%$. In the control fruit, the loss was 7.98 $\pm 0.15 \%$ (Table. 3 ). 
Table.1 Effect of different concentrations of essential oils and synthetic fungicide on spore germination of Colletotrichum gloeosporioides in vitro after 24 hours of incubation.

\begin{tabular}{|c|c|c|c|}
\hline \multirow{2}{*}{ Products } & \multicolumn{3}{|c|}{ Essential oils Synthetic fungicide } \\
\cline { 2 - 4 } Doses (ppm) & Melaleuca quinquenervia & Cymbopogon citratus & Azoxistrombin \\
\hline $\mathbf{1 0 0}(\mathbf{0 . 0 1})$ & $40.2 \pm 9.6 \mathrm{c}$ & $89.7 \pm 3.2 \mathrm{a}$ & $\mathbf{7 1 . 7} \pm \mathbf{6 . 8} \mathbf{~ a b}$ \\
\hline $\mathbf{2 0 0}(\mathbf{0 . 0 5})$ & $52.2 \pm 7.8 \mathrm{c}$ & $92.5 \pm 2.9 \mathrm{a}$ & $\mathbf{7 8 . 3} \pm \mathbf{4 . 1} \mathbf{~ a b}$ \\
\hline $\mathbf{5 0 0}(\mathbf{0 . 1})$ & $58.7 \pm 8.2 \mathrm{c}$ & $98.3 \pm 1.2 \mathrm{a}$ & $\mathbf{8 6 . 3} \pm \mathbf{2 . 8} \mathbf{~ a b}$ \\
\hline $\mathbf{1 0 0 0 ( \mathbf { 0 . 5 } )}$ & $81.1 \pm 4.6 \mathrm{a}$ & $100 \pm 0.0 \mathrm{a}$ & $\mathbf{9 4 . 2} \pm \mathbf{1 . 5} \mathbf{~ a}$ \\
\hline $\mathbf{2 0 0 0}(\mathbf{1})$ & $89.7 \pm 4.2 \mathrm{ab}$ & $100 \pm 0.0 \mathrm{a}$ & $\mathbf{9 8 . 1} \pm \mathbf{0 . 7} \mathbf{a}$ \\
\hline
\end{tabular}

Averages followed by the same letter with in each column did not differ significantly at $\mathrm{P} \leq 0.05$ according to Newman Keuls Test

Table.2 Efficacy of Cymbopogon citratus and Melaleuca quinquenervia essential oils on the development and anthracnose symptoms evolution in Kent mangoes variety treatment before or after inoculation

\begin{tabular}{|c|l|l|l|l|}
\hline Treatments & Lesion rate (\%) & Efficiency E (\%) & Lesion size (cm) & Efficiency F (\%) \\
\hline Co & $58.33 \pm 4.49 \mathrm{a}$ & & $0.64 \pm 0.08 \mathrm{a}$ & \\
\hline $\mathbf{C 1 p}$ & $43.33 \pm 4.73 \mathrm{~b}$ & $39 \pm 6.08 \mathrm{c}$ & $0.63 \pm 0.09 \mathrm{a}$ & $15.58 \pm 10.82 \mathrm{c}$ \\
\hline $\mathbf{C 2 p}$ & $36.00 \pm 4.58 \mathrm{c}$ & $51.28 \pm 6.07 \mathrm{~b}$ & $0.22 \pm 0.03 \mathrm{c}$ & $71.75 \pm 4.84 \mathrm{a}$ \\
\hline $\mathbf{C 1} \mathbf{C}_{\mathbf{C}}$ & $32.33 \pm 4.23 \mathrm{c}$ & $54.08 \pm 5.33 \mathrm{~b}$ & $0.39 \pm 0.06 \mathrm{~b}$ & $54.33 \pm 6.83 \mathrm{~b}$ \\
$\mathbf{C 2}_{\mathbf{C}}$ & $25.00 \pm 13.01 \mathrm{~d}$ & $\mathbf{6 8 . 3 3} \pm \mathbf{4 . 1 6} \mathbf{a}$ & $0.18 \pm 0.03 \mathrm{c}$ & $\mathbf{7 9 . 2 0} \pm \mathbf{3 . 5 9} \mathbf{a}$ \\
\hline $\mathbf{C c}$ & $18.50 \pm 3.33 \mathrm{e}$ & $\mathbf{7 5 . 6 4} \pm \mathbf{9 . 9 6} \mathbf{a}$ & $0.14 \pm 0.03 \mathrm{c}$ & $\mathbf{8 5 . 8 8} \pm \mathbf{4 . 8 6} \mathbf{a}$ \\
\hline $\mathbf{C p}$ & $20.33 \pm 3.48 \mathrm{de}$ & $\mathbf{7 7 . 7 6} \pm \mathbf{8 . 7 3} \mathbf{a}$ & $0.15 \pm 0.03 \mathrm{c}$ & $\mathbf{8 6 . 6 3} \pm \mathbf{5 . 2 1} \mathbf{a}$ \\
\hline
\end{tabular}

Averages followed by the same letter with in each column did not differ significantly at $\mathrm{P} \leq 0.05$ according to Newman Keuls Test

C. citratus; Curative: $\mathrm{C} 1_{\mathrm{C}}$ (700 ppm), C2 ${ }_{\mathrm{C}}(1400$ ppm); Preventive: $\mathrm{C} 1 \mathrm{p}$ (700 ppm), C2p (1400 ppm) ; M. quinquenervia, Curative: Cc (1200 ppm); Preventive: Cp (1200 ppm) ; Control: Co (00 ppm). 
Table.3 Effect of Cymbopogon citratus and Melaleuca quinquenervia essential oils on physicochemical parameters of Kent mangoes variety

\begin{tabular}{|c|l|c|c|c|c|}
\hline Treatment & Mass loss (\%) & $\begin{array}{c}\text { Firmness } \\
\text { (Kg.f) }\end{array}$ & $\begin{array}{c}\text { Soluble sugar } \\
\text { content } \\
\left({ }^{\circ} \mathbf{B r i x}\right)\end{array}$ & $\begin{array}{c}\text { Titratableacidity } \\
\mathbf{m E q . 1 0 - 2} \mathbf{~ g}\end{array}$ & pH \\
\hline $\mathbf{0 0 p p m}$ & $7.98 \pm 0.15 \mathrm{a}$ & $23.05 \pm 2.75 \mathrm{a}$ & $1.67 \pm 0.11 \mathrm{a}$ & $2.73 \pm 0.23 \mathrm{~b}$ & $4.44 \pm 0.55 \mathrm{~b}$ \\
\hline $\mathbf{7 0 0} \mathbf{~ p p m}$ & $11.94 \pm 1.68 \mathrm{a}$ & $15.20 \pm 0.58 \mathrm{~b}$ & $1.59 \pm 0.04 \mathrm{a}$ & $4.53 \pm 0.54 \mathrm{ab}$ & $5.64 \pm 0.14 \mathrm{a}$ \\
\hline $\mathbf{1 4 0 0} \mathbf{p p m}$ & $9.54 \pm 0.93 \mathrm{a}$ & $22.37 \pm 2.55 \mathrm{a}$ & $1.49 \pm 0.09 \mathrm{a}$ & $6.26 \pm 0.70 \mathrm{a}$ & $3.68 \pm 0.41 \mathrm{~b}$ \\
\hline $\mathbf{1 2 0 0} \mathbf{~ p p m}$ & $12.65 \pm 1.74 \mathrm{a}$ & $25.80 \pm 2.94 \mathrm{a}$ & $1.67 \pm 0.10 \mathrm{a}$ & $7.84 \pm 3.00 \mathrm{a}$ & $3.71 \pm 0.30 \mathrm{a}$ \\
\hline
\end{tabular}

Averages followed by the same letter within each column did not differ significantly at $\mathrm{P} \leq 0.05$ according to Newman Keuls Test.

Figure.1 Inhibitory effect of Melaleuca quinquenervia essential oil on mycelia growth of Colletotrichum gloeosporioides.

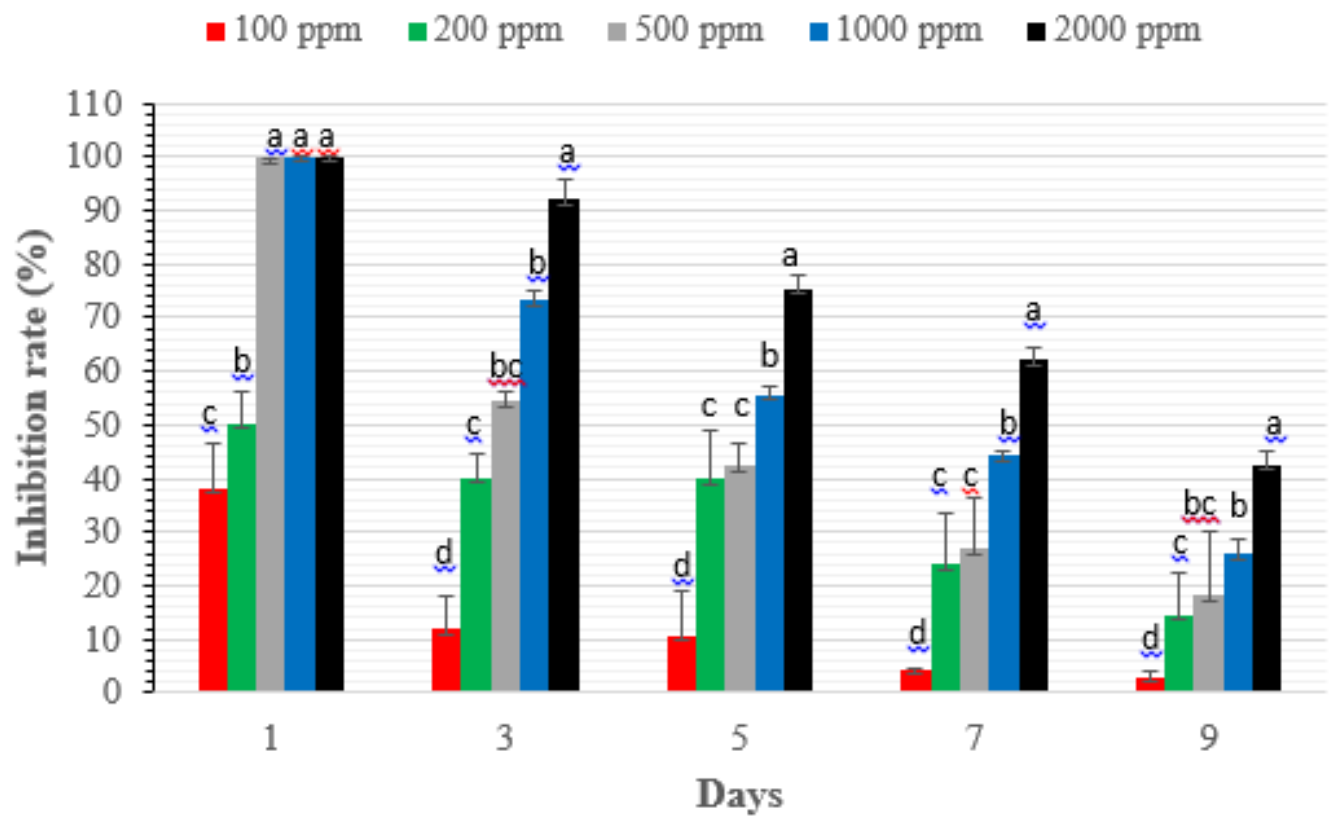

Significant differences $(p<0.05)$ among averages are indicated by letters above histogram bar. Where the letters are the same, there is no significant difference among different inhibition rates. 
Figure.2 Inhibitory effect of Cymbopogon citratus essential oil on mycelia growth of Colletotrichum gloeosporioides.

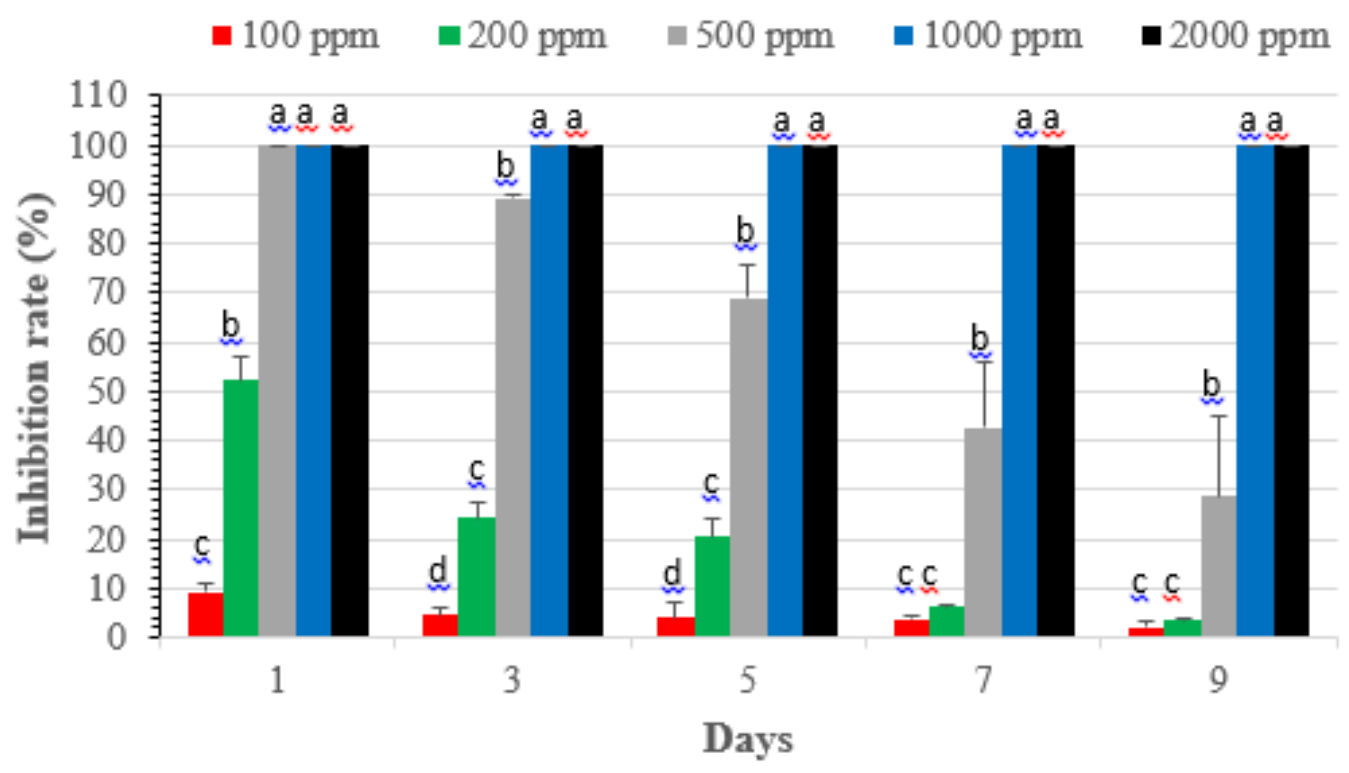

Significant differences ( $p<0.05)$ among averages are indicated by letters above histogram bar. Where the letters are the same, there is no significant difference among different inhibition rates.

Figure.3 Inhibitory effect of the synthetic fungicide "Azoxystrombin on mycelial growth of Colletotrichum gloeosporioides.

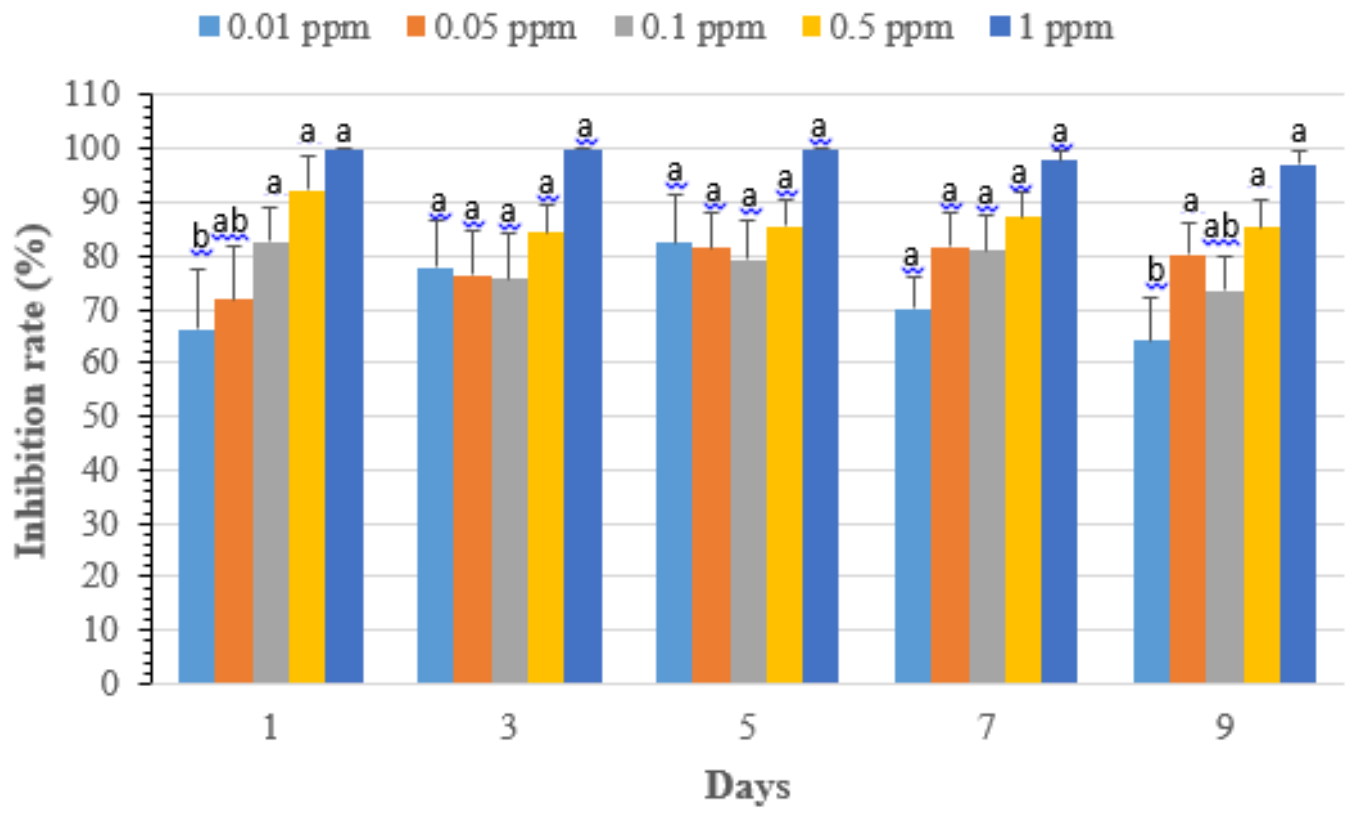

Significant differences $(p<0.05)$ among averages are indicated by letters above histogram bar. Where the letters are the same, there is no significant difference among different inhibition rates. 
Figure.4 Effect of Cymbopogon citratus essential oil on the development of anthracnose in Kent mangoes inoculated before or after treatment as a function of time

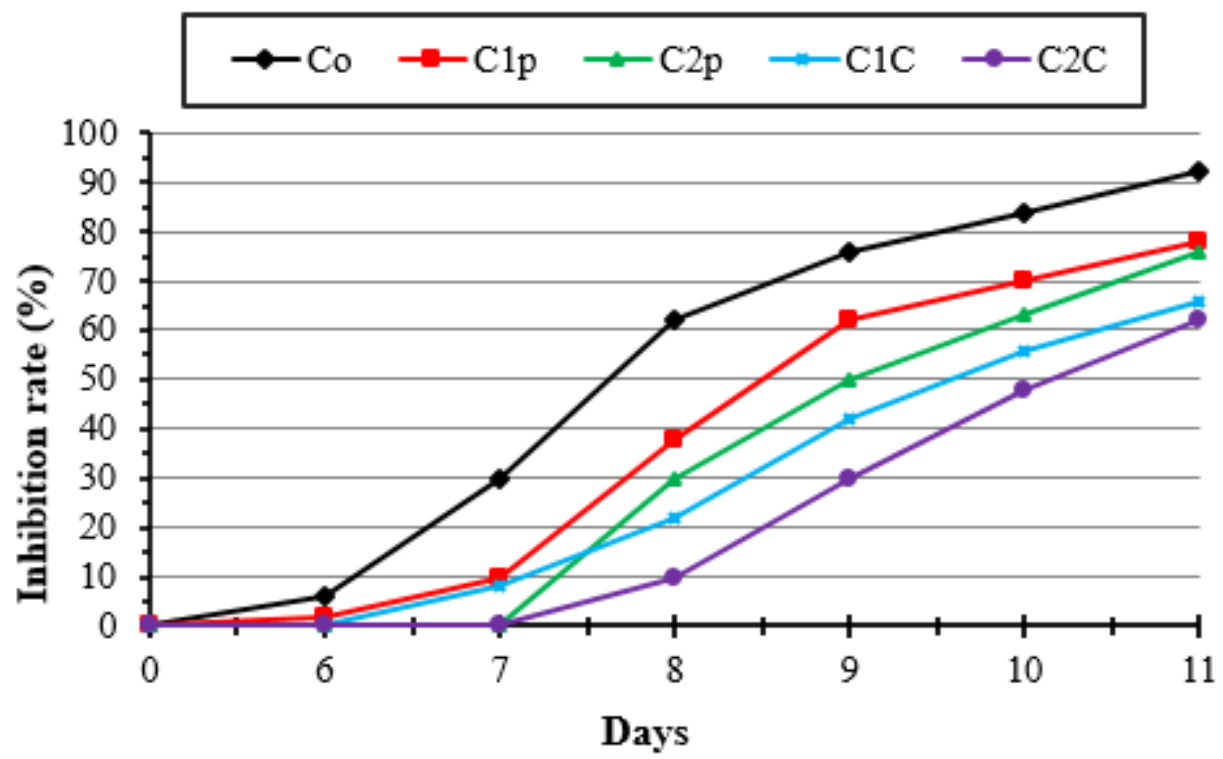

Control: Co (00 ppm); Curative: C1C (700 ppm), C2C (1400 ppm); Preventive: C1p (700 ppm), C2p (1400 ppm)

Figure.5 Effect of Melaleuca quinquenervia essential oil on anthracnose development of Kent mangoes treated before or after inoculation as a function of time.
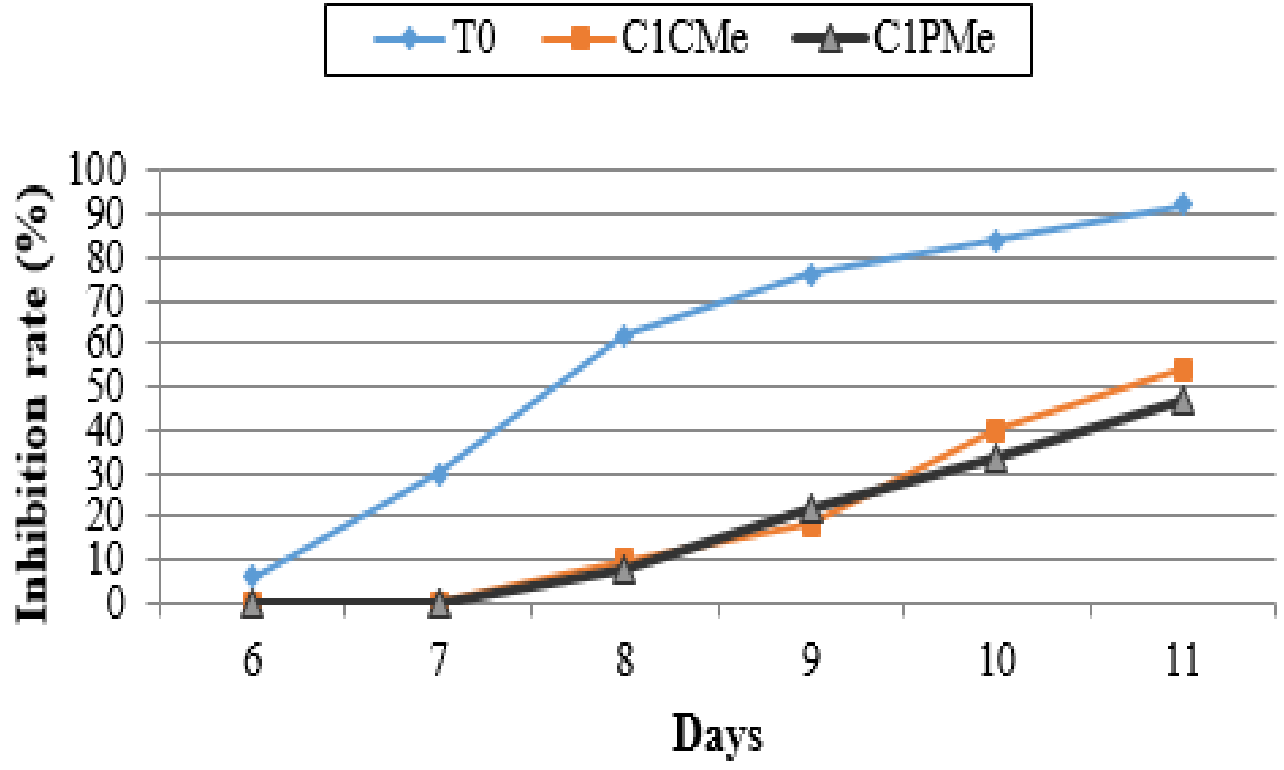

Curative :C1CMe (1200 ppm) ; Preventive : C1Pme (1200 ppm) ; Control : T0 (00 ppm) ; 


\section{Firmness}

C. citratus essential oil induced a firmness of $15.20 \pm 0.58 \mathrm{Kg} . \mathrm{f}$ in the treated fruits with dose C1 (700 ppm), followed by $22.37 \pm 2.55$ Kg.f with dose C2 (1400 ppm) and $23.05 \pm$ $2.75 \mathrm{Kg}$.f with the control fruits. The $\mathrm{C} 1$ dose significantly influenced fruit firmness $(p=$ 0.0066). On the other hand, fruits treated with dose C2 (1400 ppm) showed a statistically identical firmness to that of the controls $(p=$ 0.127589; Table 3). The $\mathrm{C}_{\mathrm{M}}$ dose of $M$. quinquenervia essential oil did not influence fruits firmness ( $p=0.886$; Table 3$)$.

\section{Soluble sugar content}

Fruits treated with $C$. citratus essential oil showed soluble sugar levels of $1.59 \pm 0.04$ ${ }^{\circ}$ Brix with the $\mathrm{C} 1$ dose and $1.49 \pm 0.09{ }^{\circ}$ Brix with the $\mathrm{C} 2$ dose. These levels are statistically similar $(p=0.140)$ to that of the control (Table $3)$. As for the treatment with the essential oil of $M$. quinquenervia, the rate of soluble sugars obtained was $1.67 \pm 0.10{ }^{\circ}$ Brix. With the control fruits, a level of $1.67 \pm 0.11{ }^{\circ}$ Brix was recorded (Table 3 ). There was no significant difference ( $p=0.0551)$ between the soluble sugar content of the treated and control fruits (Table3).

\section{Titratable acidity}

Fruits treated with $\mathrm{C} 1$ and $\mathrm{C} 2$ doses of $C$. citratus essential oil showed an acidity of 4.53 \pm 0.54 and $6.26 \pm 0.70 \mathrm{mEq} \cdot 10-^{2} \mathrm{~g}$ (Table 3).

The titratable acidity recorded with $\mathrm{C} 2$ dose was statistically different $(p=0.0087)$ from that of the control $(\mathrm{Co}=2.73 \pm 0.23 \mathrm{mEq} .10-2$ $\mathrm{g}$; Table 3). The titratable acidity of the fruits treated with $M$. quinquenervia essential oil was $7.84 \pm 3$ mEq.10-2 g (Table.3). This treatment significantly influenced the acidity of the fruits compared to the control ( $p=$ $0.0013)$.
pH

For $C$. citratus essential oil, doses $\mathrm{C} 1$ and $\mathrm{C} 2$ produced $\mathrm{pH}$ values of $5.64 \pm 0.14$ and $3.68 \pm$ 0.41 , respectively, in the treated fruits. Dose $\mathrm{C} 1$ induced a significant change in fruit $\mathrm{pH}(P$ $=0.0001)$. It caused an increase, while $\mathrm{C} 2$ caused a reduction in fruit $\mathrm{pH}$ (Table 3). As for the treatments with the essential oil of $M$. quinquenervia, a $\mathrm{pH}$ of $4.44 \pm 0.12$ was observed with the control (00 ppm) and $3.71 \pm$ 0.30 with $\mathrm{C}_{\mathrm{M}}$ (Table 3 ). This oil did not significantly influence the $\mathrm{pH}$ of the fruits $(p=$ 0.322).

\section{Effect of essential oils on mycelial growth and spore germination of $C$. gloeosporioides}

The different doses of the two essential oils used more or less inhibited mycelial growth and spore germination of the pathogen. This indicates that the essential oils tested have antifungal properties.

The essential oil from the leaves of Cymbopogon citratus had a strong inhibitory activity compared to that of $M$. quinquenervia on both life stages of the fungal parasite, $C$. gloeosporioides (Penz.) Sacc. The minimum inhibitory concentration (MIC) was detected for $C$. citratus oil against the parasite at 1000 ppm. $M$. quinquenervia oil did not show any MIC against the same parasite. These two essences do not have the same composition. Indeed, C. citratus is composed mainly of Citral (Geranial +Neral $56.3 \%$ ) and Myrcene (23.1\%), while $M$. quinquenervia has 1,8 cineole (46.50 \%); -pinene (11.9\%), viridiflorol $(11.3 \%)$, terpineol $(9.5 \%)$ and Limonene $(08.9 \%)$. The high activity of $C$. citratus is mainly due to these two compounds. Indeed, the strong antifungal capacity of citral has been proven by previous work (26). Our results are similar to those obtained by Mishra and Dubey in (27). They reported that $C$. citratus essential oil totally 
inhibited the growth of Aspergillus flavus from $1000 \mathrm{ppm}$. Anaruma et al., (14) reported a very strong inhibitory activity of $C$. citratus oil on the mycelial growth of $C$. gloeosporioides (Penz.) Penz \& Sacc. They obtained the MIC at $250 \mathrm{ppm}(0.25 \mathrm{mg} / \mathrm{ml})$. This difference in results with ours could be attributed to the high proportion of citral $(86.06 \%)$ reportedly contained in their oil. Our the strong antimicrobial capacity of $C$. citratus essential oil justifies its numerous uses in medicine as well as in agriculture $(28 ; 29)$. The $M$. quinquenervia essential oil had a slightly lower inhibitory activity. These results are not consistent with those reported earlier by Fandohan et al., (30). They obtained in vitro MIC of mycelial growth of Fusarium verticillioides with $M$. quinquenervia essential oil on days 7 and 14. This difference may be related to the fungal material used. The antifungal activities of these essential oils would be due to their lipophilic character, which interacts with the cell wall and then penetrates the plasma membrane of the fungal parasite, which becomes permeable. This results in the leakage of cytoplasmic constituents eventually leading to the death of the parasite $(31 ; 32)$. The $\mathrm{EC}_{50}$ and $\mathrm{EC}_{90}$ for mycelial growth of $C$. citratus oil are higher than those for spore germination. This suggests that $C$. gloeosporioides is more sensitive to $C$. citratus oil at the spore life stage than at the mycelial life stage. The spores would have a thinner membrane wall, of which a small amount of oil would be sufficient to disrupt it. Indeed, the thickness of spore walls can modulate the antifungal activity of an essential oil, as reported by Svircev et al., (33).

Furthermore, the $C$. citratus essential oil was as effective as the synthetic fungicide, azoxystrombin used. The latter showed no minimum inhibitory concentration (MIC) on both life stages of $C$. gloeosporioides at the doses used. These oils could therefore be used instead of azoxystrombin for control of this pathogen.

Effect of the $C$. citratus and $M$. quinquenervia essential oils against mangoes anthracnose

The C. citratus essential oil gave results confirming its antifungal capacity revealed in vitro. In addition, the oil used a postinoculation treatment provided better protection of the fruit. Thus, it could be used for post-harvest treatment of mangoes to inhibit the development and eradicate anthracnose. Similar results were reported by Anaruma et al., (14), using the same essential oil against anthracnose of passion fruit in Brazil. The $1400 \mathrm{ppm}$ dose provided full protection up to 7 days after treatment. It would seem to be the appropriate dose for post-harvest control of anthracnose on mangoes. For M. quinquenervia essential oil, the $1200 \mathrm{ppm}$ dose used provided effective protection of treated fruit. This dose had an almost identical activity for both curative and preventive methods. In sum, the $1200 \mathrm{ppm}$ dose could be recommended for post-harvest control of anthracnose in mango.

\section{Influence of essential oils on some physicochemical parameters.}

The loss of mass is a determining factor in the shelf life and maintenance of the quality of the fruit. It leads to a reduction in the turgidity, rigidity and therefore the firmness of the mango. The $1200 \mathrm{ppm}$ doses of $M$. quinquenervia resulted in a significant loss of mass of the treated fruits. This loss could be due to an increase in transpiration. Indeed, the loss of water from the fruit is mainly by transpiration through the skin (34). Contrary results were reported earlier by Espitia et al., (35). They treated papayas with the essential oils of Oregano (Origanum vulgare), cinnamon (Cinnamomum zeylanicum) and 
lemongrass (Cymbopogon flexuosus). They found that there was no significant loss of mass between the treated fruits and the controls. In contrast, concentrations of 700 ppm and 1400 ppm of the C. citratus essential oil caused similar mass losses to the control. This indicates that these doses would preserve the quality of the fruit.

The results of this study indicated that essential oils of $C$. citratus and $M$. quinquenervia did not significantly influence the firmness of the fruits. This implies that they did not act on the activity or promote the synthesis of hydrolysing enzymes. The results of this study agreed with those of Tzortzakis (36), who reported that eucalyptus and cinnamon EOs had no effect on the tomato and strawberry firmness. In the contrast, Javadpour et al., (37) reported that the essential oils from four aromatic plants (Thymus vulgaris, Salvia mirzayanii, Artemisa persica, and Rosmarinus officinalis) caused an increase in the firmness of treated mangos. This difference could be explained by the source of essential oils used.

The different doses of $C$. citratus and $M$. quinquenervia oils did not significantly influence the soluble sugar levels in the treated fruits compared to the controls. Our results are in agreement with those of Asghari et al., (38), who reported that Cumin essential oil did not influence the soluble sugar level during storage of treated Strawberry. Thus, the taste of mangoes is not affected by the essential oils used. However, the results of this study are in discordance with those of Rabiei et al., (39), who reported that thyme EOs treatment had a significant effect on the TSS of apples.

The $C$. citratus and $M$. quinquenervia essential oils caused a significant increase in the amount of acid in the treated fruit compared to the control. Similar results were found with the effect of the dose 200 ppm of Thyme essential oil on the qualitative traits of apple treated (39).

The 700 ppm dose of $C$. citratus promoted a significant increase in the $\mathrm{pH}$ of treated fruit compared to the other treatments and the control. These results contrast with those reported by Rabiei et al., (39) working on the effect of two essential oils on the qualitative and quantitative traits and storage life of apple 'Jonagold' cultivar. Indeed, they found that the $\mathrm{pH}$ value of the control fruit was higher than that of the treatments.

In sum, the doses of $C$. citratus and $M$. quinquenervia essential oils did not significantly influence the physicochemical parameters of mangoes. Thus, the essential oils used did not modulate the quality of the fruits.

Overall, the essential oil of $C$. citratus leaves showed the highest antifungal activity against C. gloeosporioides (penz.) Penz \& Sacc in vitro. Finally, the $1400 \mathrm{ppm}$ dose of $C$. citratus essential oil and $1200 \mathrm{ppm}$ of $M$. quinquenervia used as an emulsion provided strong inhibition of the development and progression of anthracnose symptoms on artificially inoculated mangoes. In addition, they did not alter the quality parameters of the treated mangoes. These doses can therefore be recommended for the treatment of mangoes against anthracnose on post harvest.

\section{References}

1. FAOSTAT. 2020. Agricultural production, crop primary database. Food and Agricultural Organization of the United Nations, http://faostat.fao.org/faostat. Consulté le 21- 03-2021.

2. Virgine, P. 2018. La mangue en Côte d'Ivoire. Fiche Producteur, FRuiTROP, 
225, 83p.

3. FIRCA. 2020. Fruit sectors pp 5-8

4. FAO. 2021. Major tropical fruits preliminary results 2020 Rome, 23p.

5. Freeman, S., Minz, D., Jurkevitch, E., Maymon, M. andShabi, E. 2000. Molecular analyses of Colletotrichum species from almond and other fruits. Phytopathol, 90 (6),608-614.

6. Peres, N., Kuramae, E., Dias, M., and Souza, N. 2002. Identification and characterization of Colletotrichum spp. affecting fruit after harvesting. Brazilian J. Phytopathol,150 (3),128-134

7. Feng, W. and Zheng, X. 2007. Essential oils to control Alternaria alternata in vitro and in vivo. Food control. 18, 11261130.

8. Chiabrando, V., Garavaglia, L. and Giacalone G. 2019. The Post harvest Quality of Fresh Sweet Cherries and Strawberries with an Active Packaging System. Foods, 8(335), 1-12.

9. E C Regulation. 2005. 396/2005 of the European Parliament and of the Council of 23 February 2005 on maximum residue levels of pesticides in or on food and feed of plant and animal origin and amending Council Directive 91/414/EEC. Off. J. Eur. Union 2005, L70, 1-16.

10. Abd-AllA, M. A., and Haggag, W. M. 2010. New Safe Methods for Controlling Anthracnose Disease of Mango (Mangifera indica L.) Fruits Caused by Colletotrichum gloeosporioides (Penz.) Journal of American Science 8 (8), 361367.

11. Kouame, K. G., Kouassi, K. N., Kassi, F. M., Bolou, B. B. A., Tuo, S., Kanko, C. and Kone, D. 2015. Antifungal Activity of Essential Oils Extracted from Monodora myristica (Gaertn), Ocimum gratissimum L. and Zingiber officinalis Roscoe on Post-harvest Anthracnose of Mango Fruit (Mangifera indica L.) Variety Kent in Côte d'Ivoire. International Journal of science, 4(12), 8-18.

12. Vandana, R. K., Mesta, K. C., Kiran Kumar, M. D., Jameel, J. and Siddanna, T. 2021. Bio Efficacy of Fungicides and Bio Agents against Colletotrichum gloeosporioides causing Anthracnose in Pomegranate. Int.J.Curr.Microbiol.App. Sci, 10(07), 457-473.

13. Coulibaly, K., Ouattara, A., Soro, S., Gogbe, F., N'guessan, W. P., Acka, K., Kouame, N., Tahi, M., Guiraud, B., Assi, M., Kone, D., Konate, I. and N'guessan, F. 2021. Biological Control of Helminthosporium mays Responsible of Maize (Zea mays L.) Helminthosporiosis through the Application of Essential Oils of Eucalyptus citriodora and Ocimum gratissimum in Côte d'Ivoire. Int.J.Curr.Microbiol.App.Sci.10(7)， 642654.

14. Anaruma, N. D., Schimidt, F. L., Teixeira, Duarte M. C., Figueira, G. M., Delarmelina C., Benato, E. A. andSartoratto. 2010. Control of Colletotrichum gloeosporioides (Penz.) Sacc. In yellow passion fruit using Cymbopogon citratus essential oil. Braz. J. of Microbiology, 41(1), 66 -73.

15. Oussou, K. R., Kanko, C., Guessend, N., Yolou, S., Kouakou, G., Dosso, M., N'guessan, Y. T., Figueredo, G. and Chalchat, J-C. 2004. Antibacterial activities of essential oils of three aromatic plants from Côte d'Ivoire. Compte Rendus Chimie, 7, 1081-1086

16. Regnier, T., Du Plooy ? G. W., Combrinck, S. and Botha, B. M. 2008. Fungitoxicity of Lippia scaberrima essential oil and selected terpenoid components on two mango post harvest spoilage pathogens. Post harvest Biology and Technology, 48, 254-258.

17. Hamad, Y. K., Fahmi, M. M., Zaitoun, F. M. and Ziyada, S. M. 2015., Role of Essential Oils in Controlling Fungi that Cause Decline Disease of Guava, Int. J. 
Pure App. Biosci. 3 (5), 143-151

18. Yehouenou, B., Ahoussi, E., Sessou, P., Alitonou, G. A., Toukourou, F. and Sohounhloue, C. K. D. 2012. Chemical composition and antimicrobial activities of essential oils (EO) extracted from leaves of Lippia rugosa A. Chev against foods pathogenic and adulterated microorganisms. African Journal of Microbiological Research, 6, 5496-5505.

19. Bahous, M., Ouazzani, T. A., Badoc, A. \& Douira, A. 2005. Effet de l'azoxystrobine sur la pyriculariose, l'helminthosporiose et la curvulariose du riz. Bull. Soc. Pharm. Bordeaux, 144, 27-46

20. Kpatinvoh, B., Adjou, E. S., DahouenonAhoussi, E., Konfo, T. R. C., Atrevi, B., Soumanou, M. M. \& Sohounhloue, D. C. K. 2017. Efficacité des huiles essentielles de trois plantes aromatiques contre la mycoflore d'altération du niébé (Vigna unguiculata L., Walp) collecté dans les magasins de vente du Sud-Bénin.Journal of Applied Biosciences, 109, 1068010687.

21. Hadizadeh, I., Peivastegan, B. and Hamzehzarghani, H. 2009. Antifungal Activity of essential Oils from Some Medicinal Plants of Iran against Alternaria alternata. American Journal of Applied sciences, 6 (5), 857-861

22. Nutter, F. W., Esker, P. D., and Coelho Netto, R. A. 2006. Disease assessment concepts and the advancements made in improving the accuracy and precision of plant disease data. European Journal of Plant Pathology, 115, 95-103.

23. Kouakou, T. K., Agneroh, T. A., Pohé, J., Tienebo, E-O. and Ohoussou, N. I. L. V. 2017. Post-harvest fungal pathogens of 'Cavendish' dessert banana and evaluation of their susceptibility to azoxystrobin in Côte d'Ivoire. European Scientific Journal, 13(21), 26- 43

24. Fawole, O. A., and Opara, U. L. 2013. Effects of storage temperature and duration on physiological responses of pomegranate fruit. Industrial Crops and Products, 47, 300-309.

25. Ali, A., Muhammad, M. T. M., Sijam K. and Siddiqui, Y. 2011. Effect of chitosan coatings on the physicochemical characteristics of Eksotika II papaya (Carica papaya L.) fruit during cold storage. Food Chemistry, 124(2), 620626.

26. Hong, K. J., Yang, H. J., Jung, H., Yoon, D. J., Mee Kyung Sang, M. S. and Jeun, Y-C. 2015. Application of volatile antifungal plant essential oils for controlling pepper fruit anthracnose by Colletotrichum gloeosporioides. Plant Pathol.J.31(3), 269-277

27. Mishra, A. K. andDubey, N. K. 1994. Evaluation of Some Essential Oils for Their Toxicity again Fungi Causing Deterioration of Stored Food Commodities. Applied and Environmental Microbiology, 60 (4), 1101-1105.

28. Koba, K., Sanda, K., Raynaud, C., Nenonen, Y., Millet, J. and Chaumont, J. P. 2004. Antimicrobial activities of essential oils of three African Cymbopogon sp. against pathogenic germs of pets. Ann. Vet. 148, 202-206.

29. Dègnon, R. G., Allagbé, A. C., Adjou, E. S. and Dahouenon-Ahoussi, E. 2019. Antifungal activities of Cymbopogon citratus essential oil against Aspergillus species isolated from fermented fish products of Southern Benin. Journal of Food Quality and Hazards Control, 6,5357.

30. Fandohan, P., Gbenou, J. D., Gnonlonfin, B., Kerstin, H., Marasas, W. F. O. and Wingfield, M. J. 2004. Effect of Essential Oils on the Growth of Fusarium verticillioides and Fumonisin Contamination in Corn. Journal of Agricultural and Food Chemistry,52, 6824-6829.

31. Luciane, C. R., Alves, E. and Douglas, C. 
do Amaral. 2010. Ultrastructural study of conidia of Colletotrichum gloeosporioides and Colletotrichum musae treated with essential oils. Interciencia, 35 (12), 912915.

32. Hoyos, J. M. A., Alves, E., Rozwalka, L. C., Aparecida de Souza, E. and Zeviani, W. M. 2012. Antifungal activity and ultrastructural alterations in Pseudocercospora griseola treated with essential oils.Ciênc. agrotec. Lavras, 36(3), 270-284

33. Svircev, A. M., Smith, R.J., Zhou, T., Hernández, M., Liu, W. \& Chud, C. L. 2007. Effects of thimol fumigation on survival and ultrastracture of Monilinia fructicola. Postharvest Biology and Technology, 45, 228-233

34. Rivera-Lòpez, J., Vazquez-Ortiz, F. A., Ayala-Zavala, J. F., Sotelo-Mundo, R. R. and Gonzalez-Aguilar, G. 2005. Cutting shape and storage temperature affect overall quality of fresh-cut papaya cv. 'Maradol'. Journal of Food Science Malden, 70(7), 482-489

35. Espitia, P. J. P., Soares, N. de F. F., Botti, L. C. M., Ramos de Melo, N., Pereira, O.
L., and Silva, W. A. 2012. Assessment of the efficiency of essential oils in the preservation of post harvest papaya in an antimicrobial packaging system. Brazilian Journal of Food Technology, Campinas, 15(4), 307-316.

36. Tzortzakis, N. G. 2007. Maintaining post harvest quality of fresh produce with volatile compounds. Innov. Food Sci. Emerg. Technol, 8, 111-116.

37. Javadpour, S., Golestani, A., Rastegar, S. and Dastjer, M. M. 2018. Postharvest control of Aspergillus niger in mangos by means of essential oil. Adv. Hort. Sci., 32(3), 389-398.

38. Asghari, A., Mostofi Y., Shoeibi Sh. and Fattahi M. 2009. Effect of cumin essential oil on post harvest decay and some quality factors of strawberry. Journal of Medicinal Plants, 8 (31), 25-43.

39. Rabiei, V., Shirzadeh, E., Rabbi Angourani, H. and Sharafi, Y. 2011. Effect of thyme and lavender essential oils on the qualitative and quantitative traits and storage life of apple 'Jonagold' cultivar. Journal of Medicinal Plants Research, 5(23), 5522-5527

\section{How to cite this article:}

Kouame Koffi Gaston, Kouame Konan Didier, Kassi Koffi Fernand Jean-Martial and Kone Daouda. 2021. Post-Harvest Control of Anthracnose of Mango (Mangifera indica L. var Kent) using Essential Oils Extracted from two Aromatic Plants (Cymbopogon citratus (D C) Stapf. and Melaleuca quinquenervia L.) of the Ivorian Flora. Int.J.Curr.Microbiol.App.Sci. 10(11): 277-293. doi: https://doi.org/10.20546/ijcmas.2021.1011.032 